\title{
Explaining the freedom of information in local government: What influences information disclosure?
}

\author{
Explicando el libre acceso a la información en el gobierno local: ¿qué influye en la \\ divulgación de información?
}

\author{
Francisca Tejedo-Romero ${ }^{1 *}$, Joaquim Filipe Ferraz Esteves Araujo ${ }^{2}$ \\ ${ }^{1}$ Departamento de Administración de Empresas, Universidad de Castilla-La Mancha, España \\ ${ }^{2}$ Universidade do Minho-Escola de Economia e Gestao, Portugal
}

Received November 17, 2018; accepted October 17, 2019

Available online October 21, 2019

\begin{abstract}
In response to the growing demand from society to access public information, governments have been forced to be more transparent in the conduct of their activities. Based on the literature of information disclosure, this paper analyses factors that influenced the freedom of information in Spanish municipalities, and which explain the levels of information disclosure. For the purpose of this study, a dynamic panel System General Method of Moments (System-GMM) estimation was used to analyses data from 100 Spanish largest municipalities for the period of 2008-2014. Additionally, the sample was partitioned in two categories according to the province capital or not province capital criteria in order to find if there are interesting differences. The analysis indicates that disclosure of information about municipal

\footnotetext{
*Corresponding author.

E-mail address: Francisca.Tejedo@uclm.es (F. Tejedo Romero).

Peer Review under the responsibility of Universidad Nacional Autónoma de México. 
management is associated with financial dependence, internet access, unemployment, electoral turnout and political rivalry. Differences found in the two categories of municipalities suggest that there may be institutional characteristics that could influence the dissemination of information. This study is a contribution to the growing body literature of information disclosure in order to understand what explains the variations of information disclosure among the municipalities.

JEL codes: $\mathrm{H} 70, \mathrm{H} 79, \mathrm{H} 80$

Keywords: Information disclosure; Transparency; Local government; Freedom of information; Municipalities

\section{Resumen}

En respuesta a la creciente demanda de la sociedad para acceder a la información pública, los gobiernos se han visto forzados a ser más transparentes en el desarrollo de sus actividades. Basado en la literatura de divulgación de información, este artículo analiza los factores que influyeron en el libre acceso a la información en los municipios españoles y que explican los niveles de divulgación de información. A los efectos de este estudio, se utilizó la estimación del Método Generalizado de Momentos (GMM) de Sistema (System-GMM) de datos de panel en un modelo dinámico para analizar los datos de 100 municipios españoles más grandes para el período 2008-2014. Además, la muestra se ha dividido en dos categorías según el criterio de si los municipios son capital de provincia o no para determinar si existen diferencias interesantes. El análisis indica que la divulgación de información sobre la gestión municipal está asociada con la dependencia financiera, el acceso a internet, el desempleo, la participación electoral y la rivalidad política. Las diferencias encontradas en las dos categorías de municipios sugieren que puede haber características institucionales que podrían influir en la divulgación de información. Este estudio es una contribución a la creciente literatura sobre divulgación de información con la finalidad de comprender qué explica las variaciones de divulgación de información entre los municipios.

Código JEL: H8, H79

Palabras clave: Divulgación de información; Transparencia; Gobierno local; Libre acceso a la información;

Municipios

\section{Introduction}

In recent decades, the pressure to make public organizations more transparent and the Freedom of Information laws ${ }^{1}$ (FOI), altered the traditional culture of Public Administration and increased information disclosure, reinforcing the ability of the public to access government information (Piotrowski \& Van Ryzin, 2007).

\footnotetext{
${ }^{1}$ The Freedom of Information laws are regulations which gives every citizen the right to request certain information held by the public bodies and organisations, including the government, regulators and any public service companies.
} 
Information disclosure is a mechanism to improve the public trust, and hold politicians and officials accountable for their actions and outcomes (Park \& Blenkinsopp, 2011). It has increased worldwide in the public sector under the designation of transparency and it is an indirect effect promoted by New Public Management and New Public Governance (Gonzalez, Gasco \& Llopis, 2007; Osborne, 2006), by opening public organizations, and increasing the mechanisms of communication, accountability and transparency. Concerning the disclosure of municipal information, it is worthwhile to build up its understanding (Greco, Sciulli \& D'onza, 2012). Efficient use of scarce resources requires effective mechanisms to disseminate information about municipalities' decision-making, to improve public sector communication and confidence.

The issues influencing information disclosure are complex and been the result of internal and external factors of the municipalities. Previous research has indicated that information disclosure in local governments depend on political and socio-economic factors (Albalate, 2013; Tejedo-Romero \& Araujo, 2018). Other studies analyse internal factors like culture (Lopes \& Serrasqueiro, 2017). However, there is still ambiguity in results and researchers cannot make consistent conclusions (Cucciniello, Porumbescu \& Grimmelikhuijsen 2017). Maybe the inconsistency of these results lies in the design of the studies (Alcaide-Muñoz, Rodríguez-Bolívar, \& López-Hernández, 2017), or in the implementation of information disclosure policies in countries with different administrative culture whose internal and external factors of the municipalities influence information disclosure (Rodríguez, García \& Gallego, 2011). However, there is still insufficient empirical evidence to clearly establish the influence of such factors in information disclosure (Alcaide-Muñoz et al., 2017). Lowatcharin and Menifield (2015) point out the need to further development concerning the factors influencing the levels of transparency. In this regard, Cucciniello et al. (2017) propose the way forward suggesting to academics to do similar studies in order to systematically identify contextual conditions that affect transparency outcomes, and conduct analyses using different approaches.

Research shows there are important factors that explain the level of information disclosure in municipalities (Alcaraz-Quiles, Navarro-Galera \& Ortiz-Rodríguez, 2015; Piotrowski \& Van Ryzin, 2007). In the case of Spanish municipalities, it is worth to analyse information disclosure through internet communication to facilitate active information, since internet has been an important tool for information disclosure. This study uses the transparency index as a proxy of information disclosure, and identify the factors that affect information disclosure, in particular the regional effect on transparency. The choice of conducting this analysis in Spanish municipalities has to do with their problems with information disclosure, which are more frequent at local level (Cuadrado-Ballesteros, 2014). Firstly, because social pressure exerted by citizen movements, as the case of the "los indignados", compels municipalities 
to improve management efficiency, and be more transparent in the management of public resources. Secondly, the financial crisis pressured for more transparency in the management of public resources, particularly those funds come from central or regional transfers. In both cases, internet access, as a toll for information disclosure, played an important role. Hence, information disclosure and transparency may have an important role within the communication process by opening organizations to responsive communicative practices towards citizens.

This paper contributes to both the academic and practical field on information disclosure analysing internal and external factors that influence municipalities to disclosure information. With respect to the academic field, it empirically tests a theoretical framework explaining, within the communication process, what influenced information disclosure in Spanish municipalities between 2008 and 2014. Additionally, the sample was partitioned in two categories according to the province capital or not province capital criteria in order to find if there are interesting differences. It intends to contribute to the vein of research that studies the factors influencing municipalities' information disclosure with impact on communication practices. For this purpose, this study does an econometric analysis considering spatial and temporal effects (municipalities-years, panel data methodology) improving the efficiency of econometric estimates by capturing unobservable heterogeneity (Baltagi, 2014) and is especially relevant in view of the empirical robustness of this study. Arapis and Reitano (2018) point out that panel data analysis is necessary to improve the understanding of transparency and its evolution over time. It provides the analysis with a certain degree of dynamism, achieving both greater consistency and better explanatory power. However, other studies which use panel data methodology (Albalate, 2013), do not take into account a series of problems that arise when using panel data methodology, namely the cross-sectional dependence, groupwise heteroskedasticity and autocorrelation, as well as the possible endogeneity problem. This study mitigates these problems by using the System- GMM estimator for a dynamic model of panel data.

Pertaining to practitioners, the outcomes of this study bring insights into local governments, particularly by answering the following central research question: what factors influenced municipalities' information? The findings could help identify the conditions which ensure that municipalities are more transparent, since the level of transparency is the consequence of the effective communication practices within municipalities. In fact, the use of transparency has been advocated in public relations for decades.

The rest of the paper is organized as follows. The next section discusses the theoretical framework of information disclosure that will guide the analysis, and the factors that influence such disclosure. Then, the research methodology and the model will be presented, while providing data description, followed by the empirical analysis of the results and discussion of the main findings. Finally, the paper will focus on the main conclusions. 


\section{Information Disclosure as a mechanism of Good Governance}

Current scholarship and practices emphasize the benefits of openness in the disclosure of information and the process of communication. Demand for information disclosure grew rapidly, with organizations, in both the private and public sectors, being encouraged to be more transparent (Ball, 2009). Information disclosure became an important item in the agenda of nearly every organization, not only to open the government and make it more accountable, but also as a means of addressing the loss of public trust in government and improving the process of communication.

The literature on transparency presents a diversity of concepts, stressing three main issues:

a) make public organizations' decisions and actions more accountable to citizens, b) reduce government secrecy and, c) provide information to the public by several mechanisms in order to have accountable officials and decisions (Ball, 2009). According to Ellis and Fender (2006), transparency allows individuals to find out what is happening inside the government through various information disclosure mechanisms. It is a means to improve government outcomes, administrative and managerial effectiveness, as well as policy effectiveness, by conducting public affairs in the open or be subject to public scrutiny. It includes the legal, political, and institutional structures that make information on public organizations available to actors, both inside and outside the domestic political system. Although such transparency does not ensure accountability, or the end of corruption, it does make it more likely. Moreover, several communicators recognize the positive effects for democracy resulting from transparent communication practices and the existence of a public informed about government actions.

Information disclosure goes beyond the mere access to information, demanding information to be understandable to external stakeholders (Araujo \& Tejedo-Romero, 2016).

The literature on information disclosure refers four main principles. First, information about public organizations' activities affecting citizen interests should be available to the public. Second, such information should be adjusted to the influence that those organisations have in the interests of citizens. Third, the information should be accessible to those who use it, and, finally, social, political, and economic structures of society should be organized in ways that allow citizens to take action (Ball, 2009; Fung, 2013).

Disclosing information is the decision to make public the acts of the government and its representatives, and provide the civil society with relevant information in a complete, reliable, timely, easily comprehensible and reachable way. Disclosure information decision depends from external and internal factors of the municipalities. The role played by those factors are critical in information disclosure. The external factors can impose or pressure for information disclosure, for instances pressures from citizens and governments, while internal factors, like culture and other organizational characteristics, influence openness and willingness to 
disclose information. Nevertheless, information disclosure about government activities and public policies is a core issue in transparency (Alcaraz-Quiles et al. 2015; Armstrong, 2011). This contributes towards more accurate public information, and a reduction of the information deficit and asymmetry between citizens and government. Consequently, it improves the permanent dialogue between policy makers and citizens during the decision-making process. It boosts the level of confidence of citizens in their government and promotes greater civic participation. It is essential for good governance and for the promotion of honest and ethical governments (Bauhr \& Grimes, 2013; Park \& Blenkinsopp, 2011). In other words, the most important part of a public communication process is that governments communicate in an open, honest and timely way with their citizens, without manipulating the information they share. Improving the quality of good governance requires improvements of information disclosure levels.

\section{How does one measure information disclosure?}

There are two main approaches to quantify and measure the information provided by organizations. The first approach uses content analysis (Krippendorff, 2004), which is a method of coding text content into categories based on selected criteria. The second is the construction of a disclosure index that compares and explains the differences in the scope and breadth of information disclosure. The creation of a disclosure index is based on the general principles of content (or thematic) analysis as a method established in social sciences. For the purpose of this study, the transparency index is used as a proxy for information disclosure, meaning the ability of the public to access government information (Piotrowski \& Van Ryzin, 2007; Roberts, 2006). According to Krippendorff (2004), an index is a form of inference that can be performed on content analysis, and it is defined as a variable whose importance in a given investigation depends on the degree to which a correlate of other phenomena may be considered. It is an instrument designed to measure a number of items which, when the values are added, provides an indicative value of the level of disclosure in a specific context.

Therefore, the Spanish municipalities' transparency index (TI), published by Transparency International Spain, is used to explore the drivers of Municipal public information disclosure.

\section{Theoretical background of Transparency}

Since the 1970's, Local Government transparency has been a concern for scholars, particularly focused on factors promoting more and better disclosure of public financial information (Rodríguez-Bolívar, Alcaide-Muñoz \& López-Hernández, 2013). Literature about transparency is based on the explanations provided by the agency theory and the legitimacy theory (Patten, 1992; Suchman, 1995). Agency theory regards elected officials as agents who act in 
the interest of citizens, the principal (Laswad, Fisher, \& Oyelere, 2005). In such relationship, some problems can arise when there is information asymmetry (Eisenhardt, 1989). Elected officials do not have the same interests as citizens, and therefore, must be held accountable for their actions, namely by proving they have acted according to their responsibilities. In the same way, transparent communication practices and information disclosure, by voluntary or compulsory provisions, has been a way to monitor the actions of elected officials (Laswad et al., 2005), and reduce information asymmetries. It expands the level of transparency and confidence in the government (Bauhr \& Grimes, 2013). Hence, agency relationships between public sector organizations and citizens generate an incentive for politicians and public managers to disclose and increase the information offered by these entities, thus allowing their activities to be controlled and scrutinized by citizens and society.

On the other hand, Legitimacy Theory claims that information disclosure is a way for organizations to legitimize their actions towards citizens. Legitimacy is "a generalised perception or assumption that the actions of any entity are desirable, proper, or appropriate within some socially constructed system of norms, values, beliefs and definitions" (Suchman, 1995, 574). Information disclosure about organization's activities is a way to legitimize their actions before their stakeholders, and award legitimacy to organizations (Patten, 1992). The theory claims that, if organizational legitimacy is threatened, organizations will disclose information in an effort to promote it. The dissemination of information may be used to win citizens trust back, and represent an attempt to change their perceptions about the functioning of the organization. In addition, offering an image of good governance in response to general pressures is a way to secure legitimacy, and enhance local government reputation (Pina, Torres \& Royo, 2010).

These theories help us understand information asymmetry in political contexts, and the need for information disclosure and transparency. However, they do not explain which factors actually influence information disclosure. Since social and economic developments in Spain pressured politicians for greater openness to make public organizations more accountable and transparent it is worth to empirically test the influence of socioeconomic and political factors on the level of transparency.

\section{Transparency in Spanish Municipalities}

Spanish municipalities are adapting to society's demand for more transparent communication practices and transparency. Moreover, there are international organizations evaluating the level of information disclosure in different countries, including Spain. The construction of a transparency index by Transparency International Spain offered the opportunity and aroused the interest for such analysis. The Transparency Index focuses primarily on proactive communication of information by municipalities. Access to public information at local 
government level plays an essential role in the overall perception of the existence, or not, of an open government. The workings of a government will be more transparent if there is more information available and understandable, and the decision- making processes are more accessible (Armstrong, 2011). According to the Agency Theory (Laswad, et al., 2005), disclosure of information responds to internal and external pressures for transparency, reducing information asymmetry. Spanish social movements and the pressure from central government for fiscal control over municipalities were external sources to pressure for more transparency. In the same way, the response from municipalities could be influence municipal executive ideology and its financial dependence from central government. The financial dependence from external funds require that municipalities should disclosure more information about financial management to hold elected officials accountable for their actions. Information disclosure, either as voluntary or compulsory, has been a way to reduce information asymmetries, and to increase the degree of confidence and public trust in political players (Fung, 2013) enhancing municipalities' reputation. It enhances legitimacy of elected public officials (Patten, 1992), producing a positive effect on public perceptions about political decisions, projecting an image of good governance.

Another factor that affects communication and information access, are the Information and communication technologies (ICTs), such as the Internet, which have revolutionized the way society communicates and interacts. This is also true in the relationship between institutions, citizens, and the various levels of government. The provision of information and documents in the municipalities' websites enables them - regardless of their size and/or resources - to provide information to citizens about their organization, activities, and decisions. The use of the Internet by local governments for proactive communication and dissemination of information has several advantages. It creates monitoring and control mechanisms, which is a way to enhance citizen's power vis-à-vis local government (Laswad et al., 2005). It also allows citizens to participate in public management in a more informed manner, thus leading to an increase in representation, and strengthening the democratic system.

To explore what drives municipalities' information disclosure, this study used the Spanish municipalities' transparency index (TI) published by Transparency International Spain (TISpain). This index has been used in some previous studies (Albalate, 2013), and is based on the collection of information and questionnaires sent out to municipalities. The study used data from Transparency International Spain from 2008 to 2014, as a proxy for information disclosure.

\section{Factors Affecting Municipalities' Information Disclosure}

Some studies focus on internal factors to explain transparency in public organizations (Ruijer, 2016). However, the evidence is not unequivocal because of the limitations of data 
gathered and econometric analysis. Other studies about financial transparency focus on political and socioeconomic factors (Guillamón, Bastida \& Benito, 2011; Caba-Pérez, Rodríguez-Bolivar, \& López-Hernández, 2014). Proactive information disclosure by municipalities may be conditioned by the existence of certain factors which may influence and encourage the dissemination of information. In the period analysed there was pressures from social movements claiming for more transparency about public service management and accountability from politicians. The internet and social networks were important tool in information disclosure. Drawing from and expanding upon prior works the model build took as its reference the previous literature and argues that municipalities' predisposition for transparency was influenced by the following internal and external factors of the municipalities: Financial Dependence, Internet access, Unemployment, Electoral Turnout, Political Rivalry, and Political Ideology. It examines these previously mentioned variables because they constitute the common basis of the existing models in academic literature. The objective of this paper is to build up an explanatory model, supported by the agency and the legitimacy theories that apply valid operationalization of these factors and test their relative importance in Spanish municipal information disclosure. Additionally, it was controlled contextual Spanish municipal characteristics such as, population size, citizens level of educations and regional effect, which were including as control variables (see control variables in Research Methodology section). The hypotheses are developed and proposed below.

Financial Dependence. Much of the local revenue comes from central or supranational government transfers. Financial dependence plays an important role in information disclosure by local governments. The greater the financial dependence, the more accounting information municipalities have to disclose, and more transparency is required, to account for the use of funds received. Accountability and information disclosure by transparent communication are a critical part of financial control. According to the Agency Theory (Laswad et al., 2005), it is expected that when government funds are received, municipalities disclose information accounting for the use of such funds, whilst seeking to demonstrate that public managers have acted according to their responsibilities (Ingram \& DeJong, 1987).

Empirical studies, such as those conducted by Ingram and DeJong (1987), have concluded that, when a municipality receives a higher proportion of its total income as transfers of funds from state and regional governments, this is an incentive to greater disclosure of financial information, in order to demonstrate the transparent management of resources received. Alcaide-Muñoz, Rodríguez-Bolívar and López-Hernández (2013) and Guillamón et al. (2011) found that municipalities that receive larger transfers report more financial information, and are more transparent. However, studies by Caba-Pérez, Rodríguez Bolívar and López Hernández (2008) and Laswad et al., (2005) found no significant relationship between transfers received by the municipality and its disclosure of information. Furthermore, Ortiz-Rodríguez, Navar- 
ro- Galera and Alcaraz-Quiles (2015), detected that the sustainability information disclosed by Anglo-Saxon Local Governments is influenced by financial dependence. Therefore, the following hypothesis is proposed:

H1: There is a positive relationship between Financial Dependence and the level of information disclosure.

Internet Access. Internet has been widely used as a tool for disseminate information, making access to information much easier for citizens. The level of internet access by citizens is considered an important and determinant factor of transparency (Pina et al., 2010). The more people have access to internet, the greater their ability to access the municipality's website and demand an efficient, accountable, and transparent government (Caba-Pérez et al., 2014). This pressure will lead to a municipal response to be more transparent. Increasing the level of information available to citizens is an important contribution to reduce the information asymmetry associated with the agency problem (Lane, 2005). According to the legitimacy theory, this could be an opportunity for politicians to legitimize their actions and increase citizens' confidence in government (Tejedo-Romero \& Araujo, 2018). As a response, municipalities will try to disclosure more information. Therefore, the following hypothesis is proposed: $\mathrm{H} 2$ : There is a positive relationship between the level of Internet access in a municipality and the level of information disclosure.

Unemployment. The unemployment rate has been used as a proxy variable to analyse the relationship between a municipalities' economic status and information disclosure (Cuadrado-Ballesteros, 2014; García-Sánchez, Frías-Aceituno \& Rodríguez-Domínguez, 2013). Research shows a positive relationship between economic status and information disclosure in Public Administration (Piotrowski \& Van Ryzin, 2007). According to the theory of legitimacy (Laswad et al., 2005), being transparent is one way to recover the loss of confidence from citizens. It is plausible to expect that in periods of economic and financial crisis, the level of unemployment may increase. As a consequence, the municipal economic status will decrease, together with the level of information disclosure. Therefore, as Albalate (2013) and Caamaño-Alegre, Lago-Peñas, Reyes-Santias and Santiago-Boubeta (2013) empirically found, high unemployment rates are significantly related to low levels of information disclosure. Therefore, the following hypothesis is proposed:

$\mathrm{H} 3$ : There is a negative relationship between the rate of unemployment in a given municipality, and the level of information disclosure.

Electoral Turnout. Citizen's concern with politics, expressed by electoral turnout, demands more information disclosure from public organisations (Albalate, 2013). The level of electoral turnout might indicate the lower or higher interest in local government's activities, therefore more or less pressure to access information. Information disclosure and greater transparency in communication, aiming to promote political interest and citizen involvement, 
may increase electoral turnout. This may boost citizens' involvement in politics, influencing the level of electoral turnout (Araujo \& Tejedo-Romero, 2016) and, according to the agency theory, reduce information asymmetry. The legitimacy theory suggests that, in the case of lower electoral turnout, the government will increase transparency to win back citizens' trust and change their perceptions about public organizations' functioning (Albalate, 2013). On the other hand, an image of good governance can increase the organizations' legitimacy (Patten, 1992; Roberts, 2006) and citizens' confidence in political players (Laswad et al., 2005). The following hypothesis is thus established:

H4. There is a negative relation between electoral turnout in a given municipality and its transparency index.

Political Rivalry. The presence or absence of strong opposition to monitor the ruling group, influence opportunistic behaviour from politicians (Cárcaba-García \& García-García, 2010; Zimmerman, 1977). Opposition parties will be keen on prompting information about local government activities that are not in accordance with electoral promises and will claim irresponsible management (Baber \& Sen, 1984). The higher the political rivalry, the higher the incentives to disclosure information from elected politicians to supply monitoring information to show that they are honouring pre-election promises (Baber, 1983). Political rivalry creates incentives to reduce agency problems and information asymmetry and pressures the disclosure of information about the activities of the ruling political party. Therefore, the following hypothesis is postulated:

H5: There is a positive relationship between the level of political rivalry and information disclosure.

Political Ideology. Several research studies show a strong relationship between political ideology and information disclosure (García-Sánchez et al., 2013; Piotrowski \& Van Ryzin, 2007). According to Albalate (2013), the governing party's ideology influences disclosure of information and transparency. According to the legitimacy argument, governments will use information disclosure to enhance their own legitimacy. Empirical studies show that left- wing parties are more prone to higher levels of information disclosure than right-wing parties (García-Sánchez et al., 2013). In spite of this, some scholars (Piotrowski \& Van Ryzin, 2007) claim that this relation is ambiguous, as both left-wing parties and right-wing parties are interested in transparency. So, the following hypothesis is established:

H6: There is a relationship between political ideology and information disclosure. 


\section{Research Methodology}

This section presents the sample used, and justifies the variables selected to test the hypotheses of the empirical study.

\section{Sample}

The sample employed to test the hypotheses comprises the 100 largest Spanish municipalities (which are the lowest level of territorial organization of the State), over a period of 5 years, for which data was published by the Organization of Transparency International Spain, namely for 2008, 2009, 2010, 2012, and 2014. From this sample, 51 municipalities are province capital.

During the period under analysis, Spain did not have a transparency law in force. The absence of compulsory information disclosure offers the opportunity to examine how certain factors influence voluntary information disclosure. In future research, it will be valuable to analyse the changes introduced by the transparency law that came into force for municipalities in 2015.

A balanced panel data with 500 observations (municipality-year) for 100 municipalities for 5 years was used.

\section{Variables and data collection}

Dependent Variable. To explore the level of information disclosure, the chosen dependent variable was the Spanish municipalities transparency index (TI), published by Transparency International Spain.

Independent Variables:

Financial Dependence. This numerical variable represents the total transfers (capital and current transfers) to total income ratio.

Internet access. It is a numeric variable calculated as the number of inhabitants with Internet access divided by population size.

Unemployment. It is the unemployment rate recorded in a given municipality, measured by the percentage of potentially active population.

Electoral turnout. This is a numerical variable representing the percentage of participation in the last local elections in the municipality.

Political Rivalry. It is a numerical variable that measures the number of political parties taking part in municipal elections.

Political Ideology. It is a dummy variable that takes up the value of 1 if the municipal ruling leader belongs to a left-wing party, and 0 otherwise. 
Control variables. To avoid biased results, the following variables, which may influence the level of transparency in municipalities and the process of communication, were introduced.

Population Size. This numerical variable is the number of inhabitants in the municipality.

Education Level. Citizens with a higher educational level might demand a greater amount of information from municipalities. This is a numerical variable that represents the level of education attained by the adult population aged between 25 and 64, especially with higher education degrees and PhDs.To consider the possible influence of institutional characteristics of those municipalities two additional variables have been considered to control for regional effects:

Regional Party. This is another variable to analyse the effect of the regional party on the levels of transparency. The regional government could play an important role in municipalities' policy choices. The alignment between the two could have an impact on the municipalities' decisions on transparency. This is a dummy variable that takes up the value 1 if the regional and municipal party are the same; and takes up the value 0 otherwise.

Region. In Spain, municipalities are nested within regions, and it is advisable to consider the effects of the region. The model has considered 17 dummy variables that correspond to the Autonomous Governments. These dummy variables take up the value 1 if the municipality belongs to a certain Autonomous Government, and 0 otherwise.

Data from independent and control variables were collected from the Spanish National Statistics Institute, Ministry of Economy and Home Affairs.

\section{Empirical model specification and estimation method}

The current research involves 100 largest Spanish municipalities and has the main objective to explore the linkage between socio-economic and political factors and the level of information disclosure over the period of 2008-2014. It is based on the assumption that internal factors of the municipalities (Financial Dependence and Political Ideology), external factors of the municipalities (Unemployment, Internet Access, Electoral Turnout and Political Rivalry) and certain contextual characteristics (control variables), influence information disclosure decisions. A balanced panel data regression method has been adopted for that purpose, and it was empirically tested by using the following econometric models:

Transparency Indexit $=\beta 0$ Transparency Indexit $1+\beta 1$ Financial Dependenceit $+\beta 2$ Internet Accessit $+\beta 3$ Unemploymentit $+\beta 4$ Electoral Turnoutit $+\beta 5$ Political Rivalryit $+\beta 6$ Political Ideology $+\beta 7$ Population Size $+\beta 8$ Education Level $+\beta 9$ Regional Party $+\beta 10$ Region + cit 
Where:

$i$ represents the 100 municipalities as $i=1, \ldots ., 100$, and $t$ is time as $t=2008,2009,2010$, 2012 and 2014. $\beta$ represents the parameters to be estimated. $\varepsilon$ represents the error term.

The model has been empirically tested by using the system-generalized method of moments - System-GMM - approach (Roodman, 2006), in line with other studies (Chortareas, Logothetis \& Papandreou, 2016). System-GMM addresses the impact of the transparency index of the past upon the current one and explores the dynamic endogeneity inherent to the explanatory variables. Additionally, robust standard errors have been estimated, using the one-step and two-step version of the System-GMM estimator with a finite-sample correction (Windmeijer, 2005). Two-step estimation with Windmeijer corrected standard errors is superior to cluster-robust one-step estimation (Roodman, 2006). The consistency of the System-GMM estimator depends on the validity of the assumption that the error terms do not exhibit serial correlation and on the validity of the instruments. To address the issues, we use the specification tests suggested by Arellano and Bond (1991) and by Blundell and Bond (1998). First, we test the hypothesis that there is no first order serial correlation of the error term. Under the null hypothesis of no serial correlation, the test statistic is distributed as a standard normal. Second, we test that there is no second order serial autocorrelation of the error term, which is distributed as a standard normal under the null hypothesis of no serial correlation. The third is the Hansen test of over-identifying restrictions and the validity of the instruments under null hypothesis of validity of instruments.

Since the size of the municipalities is relevant, the sample was partitioned in two categories according to the province capital municipalities or not province capital municipalities' criteria in order to find if there are interesting differences.

\section{Results and Discussion}

This section provides the study's empirical results by using two types of analyses. Firstly, a descriptive analysis was carried out to present the main characteristics of the Spanish municipalities included in the sample. Then, a multivariate analysis was conducted, in order to show evidence of the relationship between the proposed variables in the econometric models.

Table 1 summarises the main descriptive statistics (average, maximum and minimum value) for the variables. Panel A refers to continuous variables, while Panel B presents information on dummies variables. 
Table 1

Descriptive statistics

Panel A: Continuous Variables

\begin{tabular}{lllllll} 
& 2008 & 2009 & 2010 & 2012 & 2014 & $2008-2$ \\
\hline Transparency Index & & & & & & \\
Mean & 52.1 & 66.3 & 70.7 & 71.4 & 85.2 & 69.1 \\
Max & 90.6 & 98.8 & 100 & 100 & 100 & 100 \\
Min & 12.5 & 17.5 & 28.8 & 15 & 28.8 & 12.5
\end{tabular}

Financial Depen-

dence

Mean

33.7

41.3

38.2

26.9

32.7

34.5

Max

66

68.1

64.3

57.9

71.2

71.2

Min

13.2

22

18.9

8.73

8.57

8.57

Internet access

Mean

77.5

79.4

84

89.8

93.8

84.9

Max

85.8

88.1

92.5

94.4

96.9

96.9

Min

70.3

69.6

76.3

85.7

90.4

69.6

Unemployment

Mean

7.8

11.4

12.8

14.9

15.2

12.4

Max

14.6

20.4

21.4

23.7

25.1

25.1

Min

3.4

4.9

5.6

6.2

6

3.4

Electoral turnout

Mean

59

59

59

61.8

61.8

60.1

Max

72.7

72.7

72.7

75.2

75.2

75.2

Min

43.6

43.6

43.6

46.4

46.4

43.6

Political Rivalry

Mean

$$
8.97
$$

8.97

8.97

10.8

10.8

9.69

Max

25

25

25

25

25

25

Min

3

3

3

4

4

3

Population Size

Mean

Max

214529

216683

217406

217340

215091

216210

Min

3213271

325594

3273049

3233527

3165235

3273049

35037

35396

35241

35841

35675

35037

Education Level

\begin{tabular}{llllllll} 
Mean & 29.6 & 30.1 & 31.1 & 32.8 & 33.8 & 31.5 \\
Max & 41.7 & 43.3 & 43.7 & 46 & 46.8 & 46.8 \\
Min & 20.8 & 22.1 & 22.6 & 23.7 & 24.5 & 20.8 \\
\hline
\end{tabular}


Panel B: Dummies Variables

\begin{tabular}{lcccccccccccc}
\hline & 1 & 0 & 1 & 0 & 1 & 0 & 1 & 0 & 1 & 0 & 1 & 0 \\
$\begin{array}{l}\text { Political Ideology } \\
\text { Percentage (\%) }\end{array}$ & 54 & 46 & 54 & 46 & 54 & 46 & 25 & 75 & 25 & 75 & 42.4 & 57.6 \\
$\begin{array}{l}\text { Regional Party } \\
\text { Percentage (\%) }\end{array}$ & 56 & 44 & 56 & 44 & 56 & 44 & 57 & 43 & 57 & 43 & 56.4 & 43.6 \\
N (Observations) & 100 & & 100 & & 100 & & 100 & & 100 & & 500 & \\
\hline
\end{tabular}

Source: Own elaboration

Panel A shows that, over the years, there were increases in the value of the transparency index in the municipalities analysed, with the index taking an average value of 69.1 during the period 2008-2014, suggesting a more transparent communication process.

This increase may be due to the fact that those who govern and manage the municipality became aware that their stakeholders, especially citizens, are demanding more accountable actions from politicians as a result of mistrust. According to the legitimacy theory information disclosure and a better communication process is a way to recover that lost trust. This suggests that the level of transparency in Spanish municipalities is increasing, in order to legitimize their actions to citizens and reduce the problem of agency. These results are in line with those obtained in the work of Guillamón, et al. (2011), who observed an increase in the transparency index during 2008-2010. Also for that period, Cuadrado-Ballesteros (2014) obtained an average value for the transparency index of 62.45 for the sample of the 110 largest Spanish municipalities. A value similar to that was obtained in this study $-69.1-$ which is somewhat higher due to the inclusion in the study of the 2012 and 2014 values. The results are also consistent with those obtained by Albalate (2013) for 2012.

Concerning financial dependence, there was a strong increase in 2009, which may have been motivated by an attempt to boost the local economy through an increase in financial resources from the central government, targeting lower unemployment. However, with the worsening of the crisis and the pressures from the European Union and the central government to reduce public debt, transfers received were heavily influenced, and there was a dramatic reduction of financial dependence in 2012.

Internet access has increased in Spanish households, from an average value of 77.5 in 2008, to 93.8 in 2014. Therefore, most Spanish households have access to the Internet. Information and communication technologies have revolutionized the way society communicates and interact.

The unemployment rate has increased over the years. The most significant increase occurred between 2008 and 2009, when the economic and financial crisis started in Spain. The 
OECD forecast for the coming years estimates that there will be a weak and slow recovery of unemployment (OECD, 2014).

On the other hand, electoral turnout increased from $59 \%$ to $61.8 \%$ in the last elections. Perhaps the economic crisis and the social movements mobilized citizens to be more participative. Concerning political rivalry, the number of political parties increased in the last elections - from an average of nine political parties by municipality to eleven - maybe because of the existing mistrust among citizens, resulting from corruption issues in some local governments, and a more fragmented party system.

The amount of population has not changed much over the years, with an average value of 216,210 inhabitants for the period. The average educational level has remained stable over time, with a value of 31.5 for the period under analysis.

Panel B of Table 1 shows that, in the 2007 elections, most municipalities in the sample were ruled by left-wing parties - 54\% versus $46 \%$. However, after the last elections in 2011 , political ideology of the ruling parties in most municipalities changed radically, mainly to right-wing governments in $75 \%$ of the cases. The results of the 2011 local elections were a punishment to the left-wing ruling party at central level, resulting from the bad economic outcomes that followed the financial crisis. The extent of punishment did not take into account the good performance of left-wing parties at regional and local level, nor the cases of corruption or bad performance of some local governments ruled by right-wing parties. It was an expression of dissatisfaction with respect to left-wing parties.

The Regional Party variable shows a link between the ruling parties in each level. In the regional-municipal case, $56.4 \%$ of municipalities have the same ruling party in each level.

The results from estimating Eq. (1) are reported in Table 2, using dynamic panel SystemGMM estimation with robust standard errors. Columns 2, 3 and 4 present one-step SystemGMM regressions and columns 5,6 and 7 present two-step System-GMM regressions. In both models, the regression was estimated for each of the sample: the full sample, the sample of the province capital municipalities and the sample of not province capital municipalities. However, since the estimation results are similar for the two models (one-step and two-steps), the analysis will concentrate on the two-steps System-GMM estimation. This estimation is more robust than the one-step.

The purpose of this study is to estimate the effect of the selected variables on information disclosure, in order to identify what factors drive transparency. To reduce the influence of extreme values, unemployment variable has been winsorized at the 5 th and 95 th percentiles. In addition, the natural logarithm of population size variable has also been used. 
Table 2

Determinants of Municipal Transparency in Spain in the period of 2008-2014

\begin{tabular}{|c|c|c|c|c|c|c|}
\hline \multirow{4}{*}{$\begin{array}{l}\text { Independent } \\
\text { variables }\end{array}$} & \multicolumn{3}{|c|}{ Model One-step } & \multicolumn{3}{|c|}{ Model Two-step } \\
\hline & Full Sample & $\begin{array}{l}\text { Province } \\
\text { Cap. } \\
\text { Sample }\end{array}$ & $\begin{array}{l}\text { Not Province } \\
\text { Cap. Sample }\end{array}$ & Full Sample & $\begin{array}{l}\text { Province } \\
\text { Cap. Sam- } \\
\text { ple }\end{array}$ & $\begin{array}{l}\text { Not Prov- } \\
\text { ince Cap. } \\
\text { Sample }\end{array}$ \\
\hline & \multirow{2}{*}{$\begin{array}{l}\text { Coef. } \\
\text { (Rob. Std. } \\
\text { Er.) }\end{array}$} & \multirow{2}{*}{$\begin{array}{l}\text { Coef. } \\
\text { (Rob. Std. } \\
\text { Er.) }\end{array}$} & Coef. & Coef. & Coef. & \multirow{2}{*}{$\begin{array}{l}\text { Coef. } \\
\text { (Rob. Std. } \\
\text { Er.) }\end{array}$} \\
\hline & & & $\begin{array}{l}\text { (Rob. Std. } \\
\text { Er.) }\end{array}$ & $\begin{array}{l}\text { (Rob. Std. } \\
\text { Er.) }\end{array}$ & $\begin{array}{l}\text { (Rob. Std. } \\
\text { Er.) }\end{array}$ & \\
\hline \multirow{5}{*}{$\begin{array}{l}\text { Transparency } \\
\text { Index }_{t-1}\end{array}$} & p-value & p-value & p-value & p-value & $\mathrm{p}$-value & $\mathrm{p}$-value \\
\hline & $0.3092 * * *$ & 0.1488 & $0.3287 * * *$ & $0.2923 * * *$ & 0.1641 & $0.3220 * * *$ \\
\hline & $(0.0791)$ & $(0.106)$ & $(0.0915)$ & $(0.0895)$ & $(0.1374)$ & $(0.0945)$ \\
\hline & 0.0001 & 0.1603 & 0.0003 & 0.0011 & 0.2322 & 0.0007 \\
\hline & $0.8012 * * *$ & $0.7930 * * *$ & $0.6532 * * *$ & $0.7189 * * *$ & 0.3636 & $0.8541 * * *$ \\
\hline \multirow{2}{*}{$\begin{array}{l}\text { Financial } \\
\text { Dependence }\end{array}$} & $(0.1986)$ & $(0.297)$ & $(0.2205)$ & $(0.1849)$ & $(0.3248)$ & $(0.1999)$ \\
\hline & 0.0001 & 0.0076 & 0.0031 & 0.0001 & 0.2629 & 0.0000 \\
\hline \multirow{3}{*}{$\begin{array}{l}\text { Internet } \\
\text { access }\end{array}$} & $1.4743 * * *$ & $1.9619 * * *$ & $0.9476^{*}$ & $1.3459 * * *$ & $2.6770 * * *$ & $0.8734 * *$ \\
\hline & $(0.3794)$ & $(0.6479)$ & $(0.5474)$ & $(0.4572)$ & $(0.9406)$ & $(0.4138)$ \\
\hline & 0.0001 & 0.0025 & 0.0835 & 0.0032 & 0.0044 & 0.0348 \\
\hline \multirow{3}{*}{$\begin{array}{l}\text { Unemploy- } \\
\text { ment }\end{array}$} & $-1.9251 * * *$ & -2.0111 & $-1.6120 * *$ & $-2.5881 * *$ & $-7.8638^{*}$ & $-2.5264^{*}$ \\
\hline & $(0.6194)$ & $(1.3606)$ & $(0.7937)$ & $(1.1368)$ & $(4.3641)$ & $(1.3443)$ \\
\hline & 0.0019 & 0.1394 & 0.0423 & 0.0228 & 0.0716 & 0.0602 \\
\hline \multirow{3}{*}{$\begin{array}{l}\text { Electoral } \\
\text { turnout }\end{array}$} & $-0.7743 * * *$ & $-1.3138 * * *$ & 0.1682 & $-0.7071 * *$ & $-1.2691 * *$ & 0.0385 \\
\hline & $(0.272)$ & $(0.4587)$ & $(0.3721)$ & $(0.353)$ & $(0.5499)$ & $(0.5735)$ \\
\hline & 0.0044 & 0.0042 & 0.6513 & 0.0452 & 0.021 & 0.9464 \\
\hline \multirow{3}{*}{$\begin{array}{l}\text { Political } \\
\text { Rivalry }\end{array}$} & $1.2979 * * *$ & $1.1453^{* *}$ & $1.1129^{*}$ & $1.3752 * * *$ & 1.5043 & $1.7407 * *$ \\
\hline & $(0.3548)$ & $(0.5626)$ & $(0.6394)$ & $(0.4932)$ & $(0.9644)$ & $(0.7237)$ \\
\hline & 0.0003 & 0.0418 & 0.0818 & 0.0053 & 0.1188 & 0.0162 \\
\hline \multirow{3}{*}{$\begin{array}{l}\text { Political } \\
\text { Ideology }\end{array}$} & 2.8777 & -3.7608 & $12.2889 * *$ & 0.5337 & -4.4517 & 7.3358 \\
\hline & (4.1581) & (6.0089) & $(5.8102)$ & (4.4402) & $(6.142)$ & $(6.7511)$ \\
\hline & 0.4889 & 0.5314 & 0.0344 & 0.9043 & 0.4686 & 0.2772 \\
\hline \multirow{3}{*}{$\begin{array}{l}\text { Population } \\
\text { Size }\end{array}$} & $-7.2795 * * *$ & -3.9546 & $-9.6656 * * *$ & $-6.8757 * * *$ & -3.4706 & $-9.6189 * * *$ \\
\hline & (1.9708) & $(2.8476)$ & $(3.3882)$ & $(2.3841)$ & $(3.8264)$ & $(3.431)$ \\
\hline & 0.0002 & 0.1649 & 0.0043 & 0.0039 & 0.3644 & 0.0051 \\
\hline
\end{tabular}




\begin{tabular}{|c|c|c|c|c|c|c|}
\hline \multirow{4}{*}{$\begin{array}{l}\text { Independent } \\
\text { variables }\end{array}$} & \multicolumn{3}{|c|}{ Model One-step } & \multicolumn{3}{|c|}{ Model Two-step } \\
\hline & Full Sample & $\begin{array}{l}\text { Province } \\
\text { Cap. } \\
\text { Sample }\end{array}$ & $\begin{array}{l}\text { Not Province } \\
\text { Cap. Sample }\end{array}$ & Full Sample & $\begin{array}{l}\text { Province } \\
\text { Cap. Sam- } \\
\text { ple }\end{array}$ & $\begin{array}{l}\text { Not Prov- } \\
\text { ince Cap. } \\
\text { Sample }\end{array}$ \\
\hline & \multirow{2}{*}{$\begin{array}{l}\text { Coef. } \\
\text { (Rob. Std. } \\
\text { Er.) }\end{array}$} & \multirow{2}{*}{$\begin{array}{l}\text { Coef. } \\
\text { (Rob. Std. } \\
\text { Er.) }\end{array}$} & \multirow{2}{*}{$\begin{array}{l}\text { Coef. } \\
\text { (Rob. Std. } \\
\text { Er.) }\end{array}$} & \multirow{2}{*}{$\begin{array}{l}\text { Coef. } \\
\text { (Rob. Std. } \\
\text { Er.) }\end{array}$} & \multirow{2}{*}{$\begin{array}{l}\text { Coef. } \\
\text { (Rob. Std. } \\
\text { Er.) }\end{array}$} & \multirow{2}{*}{$\begin{array}{l}\text { Coef. } \\
\text { (Rob. Std. } \\
\text { Er.) }\end{array}$} \\
\hline & & & & & & \\
\hline \multirow{5}{*}{$\begin{array}{l}\text { Education } \\
\text { Level }\end{array}$} & p-value & $\mathrm{p}$-value & p-value & p-value & $\mathrm{p}$-value & $\mathrm{p}$-value \\
\hline & $1.7437 * *$ & 0.1479 & $2.5825^{* *}$ & $2.4537 * *$ & 2.0829 & $3.2609 * * *$ \\
\hline & $(0.8352)$ & $(1.4861)$ & $(1.0062)$ & $(1.0335)$ & $(1.9909)$ & $(1.2339)$ \\
\hline & 0.0368 & 0.9207 & 0.0103 & 0.0176 & 0.2955 & 0.0082 \\
\hline & -0.6841 & 0.9076 & 0.0208 & 0.6301 & 6.5180 & -0.7800 \\
\hline \multirow{2}{*}{$\begin{array}{l}\text { Regional } \\
\text { Party }\end{array}$} & $(1.8599)$ & $(3.3731)$ & $(2.7121)$ & $(2.4591)$ & $(5.4888)$ & $(3.4753)$ \\
\hline & 0.713 & 0.7879 & 0.9939 & 0.7978 & 0.235 & 0.8224 \\
\hline \multicolumn{7}{|l|}{ Region: } \\
\hline \multirow{3}{*}{ Aragon } & $-25.3256^{*}$ & -4.6088 & 0 & $-34.1757^{*}$ & -72.7873 & 0 \\
\hline & (13.1177) & (17.8972) & 0 & (18.7406) & $(50.9259)$ & 0 \\
\hline & 0.0535 & 0.7968 & . & 0.0682 & 0.1529 & . \\
\hline \multirow{3}{*}{ Asturias } & -7.3803 & 18.6647 & $-34.4558 * * *$ & -17.0186 & -41.5862 & $-63.2681 * *$ \\
\hline & $(8.373)$ & (13.9394) & $(11.6101)$ & $(11.7454)$ & $(41.2382)$ & (29.9172) \\
\hline & 0.3781 & 0.1806 & 0.003 & 0.1473 & 0.3132 & 0.0344 \\
\hline \multirow{3}{*}{$\begin{array}{l}\text { Balearic } \\
\text { Islands }\end{array}$} & 0.2645 & -3.6243 & 0 & -35.9422 & -84.6557 & 0 \\
\hline & $(6.6514)$ & (13.062) & 0 & $(40.395)$ & $(58.5158)$ & 0 \\
\hline & 0.9683 & 0.7814 & . & 0.3736 & 0.148 & . \\
\hline \multirow{3}{*}{$\begin{array}{l}\text { Canary Is- } \\
\text { lands }\end{array}$} & $-13.4056^{*}$ & -5.4752 & $-22.6149 * *$ & $-14.7390 * *$ & -5.1564 & $-27.4710 * * *$ \\
\hline & $(6.8993)$ & $(9.8062)$ & $(9.1927)$ & (6.8709) & $(11.2436)$ & $(10.2383)$ \\
\hline & 0.052 & 0.5766 & 0.0139 & 0.0319 & 0.6465 & 0.0073 \\
\hline \multirow{3}{*}{ Cantabria } & -5.5566 & 16.7647 & 0 & -19.3609 & -18.9557 & 0 \\
\hline & $(8.5709)$ & $(16.3687)$ & 0 & $(58.8387)$ & (34.9095) & 0 \\
\hline & 0.5168 & 0.3057 & . & 0.7421 & 0.5871 & . \\
\hline \multirow{3}{*}{$\begin{array}{l}\text { Castilla La } \\
\text { Mancha }\end{array}$} & $10.4199 *$ & $24.0728 * * *$ & $-14.7145^{*}$ & 6.0189 & -16.1104 & 9.8389 \\
\hline & $(6.0058)$ & $(8.7792)$ & $(8.231)$ & $(7.9555)$ & (27.4016) & (44.3539) \\
\hline & 0.0827 & 0.0061 & 0.0738 & 0.4493 & 0.5566 & 0.8244 \\
\hline
\end{tabular}




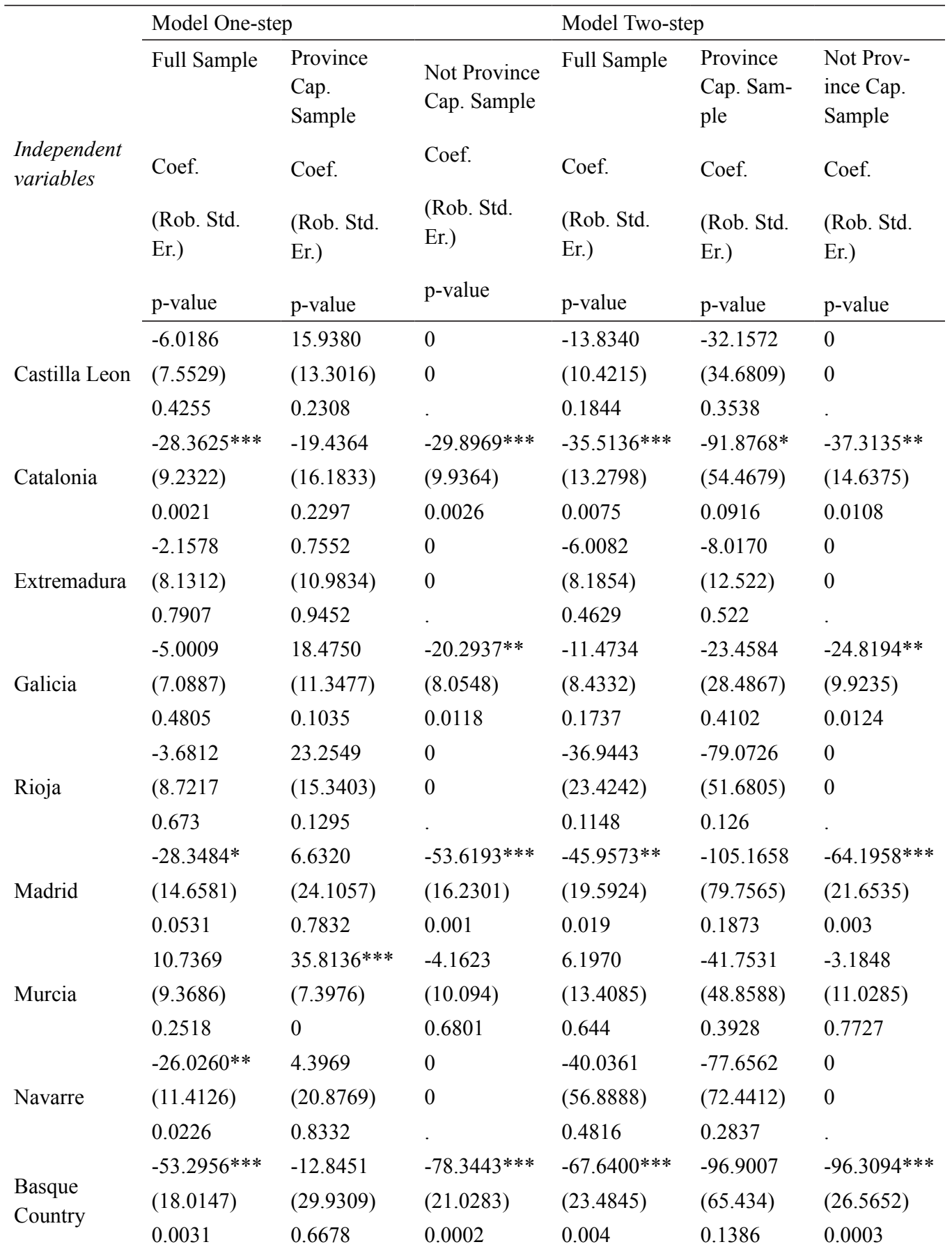




\begin{tabular}{|c|c|c|c|c|c|c|}
\hline \multirow{5}{*}{$\begin{array}{l}\text { Independent } \\
\text { variables }\end{array}$} & \multicolumn{3}{|c|}{ Model One-step } & \multicolumn{3}{|c|}{ Model Two-step } \\
\hline & Full Sample & $\begin{array}{l}\text { Province } \\
\text { Cap. } \\
\text { Sample }\end{array}$ & $\begin{array}{l}\text { Not Province } \\
\text { Cap. Sample }\end{array}$ & Full Sample & $\begin{array}{l}\text { Province } \\
\text { Cap. Sam- } \\
\text { ple }\end{array}$ & $\begin{array}{l}\text { Not Prov- } \\
\text { ince Cap. } \\
\text { Sample }\end{array}$ \\
\hline & Coef. & Coef. & Coef. & Coef. & Coef. & Coef. \\
\hline & $\begin{array}{l}\text { (Rob. Std. } \\
\text { Er.) }\end{array}$ & $\begin{array}{l}\text { (Rob. Std. } \\
\text { Er.) }\end{array}$ & $\begin{array}{l}\text { (Rob. Std. } \\
\text { Er.) }\end{array}$ & $\begin{array}{l}\text { (Rob. Std. } \\
\text { Er.) }\end{array}$ & $\begin{array}{l}\text { (Rob. Std. } \\
\text { Er.) }\end{array}$ & $\begin{array}{l}\text { (Rob. Std. } \\
\text { Er.) }\end{array}$ \\
\hline & p-value & p-value & p-value & $\mathrm{p}$-value & p-value & $\mathrm{p}$-value \\
\hline & 4.4688 & 5.2705 & -8.4144 & 1.8065 & -23.6939 & -8.4129 \\
\hline Valencia & $(5.8911)$ & $(10.8178)$ & $(7.1791)$ & $(8.1325)$ & $(25.4518)$ & $(10.523)$ \\
\hline & 0.4481 & 0.6261 & 0.2412 & 0.8242 & 0.3519 & 0.424 \\
\hline Observations & 400 & 204 & 196 & 400 & 204 & 196 \\
\hline $\mathrm{N}^{o}$ groups & 100 & 51 & 49 & 100 & 51 & 49 \\
\hline $\begin{array}{l}\mathrm{N}^{0} \text { instru- } \\
\text { ments }\end{array}$ & 50 & 50 & 43 & 50 & 50 & 43 \\
\hline $\begin{array}{l}\text { Arellano- } \\
\text { Bond test } \\
\text { for AR(1)/ } \\
\text { (p-value) }\end{array}$ & $-5.43 /(0.000)$ & $-3.84 /(0.000)$ & $-3.30 /(0.001)$ & $-4.80 /(0.000)$ & $\begin{array}{l}-3.30 / \\
(0.001)\end{array}$ & $\begin{array}{l}-3.04 / \\
(0.002)\end{array}$ \\
\hline $\begin{array}{l}\text { Arellano- } \\
\text { Bond test } \\
\text { for AR(2)/ } \\
\text { (p-value) }\end{array}$ & $1.37 /(0.170)$ & $0.36 /(0.717)$ & $1.80 /(0.282)$ & $1.33 /(0.185)$ & $\begin{array}{l}0.50 / \\
(0.615)\end{array}$ & $1.25 /(0.212)$ \\
\hline $\begin{array}{l}\text { Hansen test / } \\
\text { (p-value) }\end{array}$ & $28.48 /(0.240)$ & $\begin{array}{l}17.08 / \\
(0.845)\end{array}$ & $\begin{array}{l}20.54 / \\
(0.247)\end{array}$ & $28.48 /(0.240)$ & $\begin{array}{l}17.08 / \\
(0.845)\end{array}$ & $\begin{array}{l}20.54 / \\
(0.247)\end{array}$ \\
\hline $\mathrm{X}_{26}^{2}$ & $440.32 * * *$ & $13850.14 * * *$ & $107.17 * * *$ & $8210.95 * * *$ & $355.27 * * *$ & $2791.14 * * *$ \\
\hline
\end{tabular}

Robust standard errors with Windemeijer's finite sample correction are in parentheses. ${ }^{*} \mathrm{p}<0.1$; $* * \mathrm{p}<0.05 ; * * * \mathrm{p}<0.01$. “.” omitted variables.

Source: Own elaboration

The specification tests suggested by Roodman (2006) have been used for validation of the model by the two-step System-GMM regression. In this sense, the Arellano-Bond tests generally identified high first-order autocorrelation. The test shows that the complete estimation has an $\mathrm{AR}(1)=-4.80$ and $\mathrm{p}$-value $=0.000$, the province capital municipalities sample an $\mathrm{AR}(1)=-$ 4.80 and $p$-value $=0.000$ and the not province capital municipalities samples an $A R(1)=-3.04$ 
and $p$-value $=0.0002$. The results did not provide evidence of second-order autocorrelation with values of $\operatorname{AR}(2)=1.33, p$-value $=0.185 ; \operatorname{AR}(2)=0.50, p$ - value $=0.615 ; \operatorname{AR}(2)=1.25, p$ value $=0.212$; respectively. The Hansen tests for over- identifying restrictions confirm that the set of instruments can be considered valid (Hansen test $=28.48$, p-value $=0.240$; Hansen test $=17.08$, p-value $=0.845$; Hansen test $=20.54$, $\mathrm{p}$ - value $=0.247$; respectively). Moreover, the number of instruments (50, 50 and 43; respectively) does not exceed the number of groups (100, 51 and 49; respectively), which supports the model's correct specification and is valid. And, the $\chi 2$ shows that the overall regressions are significant $\left(\chi^{2} 26=8210.95\right.$, $\mathrm{p}$-value $=0.000$; $\chi^{2} 26=355275$, $\mathrm{p}$-value $=0.000 ; \chi^{2} 26=2791.14$, $\mathrm{p}$-value $=0.000 ;$ respectively $)$.

The lagged value of the dependent variable (Transparency Indext-1) was statistically significant at $1 \%$ level, in the full and not province capital municipalities samples $(\beta 0=0.2923$, $\mathrm{p}$-value $=0.0011 ; \beta 0=0.3220$, $\mathrm{p}$-value $=0.0007$; respectively). In other words, the amount of information disclosed depends on the amount that was provided in previous years. However, these results could not be confirmed in the case of not province capital municipalities $(\beta 0=0.1641, \mathrm{p}$-value $=0.2322)$.

It was observed that the financial dependence variable has a positive and significant effect for a significance level of 1 , in the full and not province capital municipalities samples $(\beta 1=0.7189, \mathrm{p}$-value $=0.0001 ; \beta 1=0.8541, \mathrm{p}$-value $=0.0000$; respectively $)$. Greater financial dependence in municipalities means they will be more inclined to disclose information as a way of legitimizing the actions of politicians. According to the agency and legitimacy theories, this reduces the agency problem and improves the confidence on municipalities' management. Alcaide-Muñoz et al., (2013) and Guillamón et al. (2011) found that municipalities that receive larger transfers from the state and regional governments disclose more information. However, these results could not be confirmed in the case of not province capital municipalities $(\beta 1=0.3636, \mathrm{p}$-value $=0.2629)$. Therefore, hypothesis $\mathrm{H} 1$ formulated in the theoretical framework is accepted.

Internet Access is significant at $1 \%$ level, in the full and not province capital municipalities samples $(\beta 2=1.3459$, $p$-value $=0.0032 ; \beta 2=2.6770, p$-value $=0.0044$; respectively $)$. and $5 \%$ level for not province capital municipalities sample $(\beta 2=0.8734, p$-value $=0.0348)$. The growing use of new information and communication technologies improves the communication process and allows citizens to increase their use of the Internet. It contributes to information dissemination, reducing information asymmetry. A greater access to the Internet could be a way for citizens to put pressure on municipalities to be more transparent and disclose information. The results confirm those obtained by Caba-Pérez et al., (2014) and Pina et al., (2010). Hence, hypothesis H2 is accepted.

Regarding the unemployment variable, there is a significant negative relationship for a significance level of $5 \%$ in the full sample $(\beta 3=-2.5881$, p-value $=0.0228)$ and for a signifi- 
cance level of $10 \%$ in the province capital and not province capital municipalities samples ( $\beta 3$ $=-7.8638, p$-value $=0.0716 ; \beta 3=-2.5264, p$-value $=0.0602$; respectively . As discussed in the theoretical framework, unemployment is a proxy for the economic status of municipalities. In periods of crisis, an increase in this variable is expected, and, consequently, there is a strong attempt by politicians to hide the situation, and therefore, not disclose so much information. According to the theory of legitimacy, this is an attempt not to lose the confidence of the citizens. A negative relationship has been observed, as concluded in the research of Albalate (2013) and Caamaño-Alegre et al. (2013). So, hypothesis H3 is accepted. Regarding the variable electoral turnout, it is significant at the $5 \%$ level, and it is negatively associated with the dependent variable, in the full and not province capital municipalities samples $(\beta 4=-0.7071$, $\mathrm{p}$-value $=0.0452 ; \beta 4=-1.2691, \mathrm{p}$-value $=0.021$; respectively) Hypothesis $\mathrm{H} 4$ is confirmed. It is reasonable to assume that the lower the electoral turnout, the lower the trust in municipal government. Therefore, as suggested by legitimacy and agency theories, in order to increase citizens' involvement, municipalities should provide relevant information on budgets, plans, and activities contributing to municipal transparency. However, these results could not be confirmed for municipalities that are not the province capital $(\beta 4=0.0385, \mathrm{p}$-value $=0.9464)$.

The political rivalry variable is positively correlated with the transparency index at the $1 \%$ and $5 \%$ level in the full and not province capital municipalities samples, respectively ( $\beta 5$ $=1.3752$, $\mathrm{p}$-value $=0.0053 ; \beta 5=1.7407, \mathrm{p}$-value $=0.0162$; respectively). Hence, hypothesis H5 can be confirmed. This confirms that political rivalry creates incentives to reduce agency problems and information asymmetry. In the Spanish context, García-Sánchez et al. (2013) found no significant influence of political rivalry in information disclosure. This result could not be confirmed for the not province capital municipalities $(\beta 5=1.5043$, $p$-value $=0.1188)$.

There is no significant relationship with political ideology. This result confirms other studies which argue that left-wing parties and right-wing parties are both interested in transparency. Therefore, hypothesis H6 is not confirmed.

Other factors, such as population size, citizens' educational level, and region have a significant influence in the level of municipal transparency in the full and not province capital samples. These factors are not significant for the province capital municipalities' sample. However, for all cases, there is no relationship regarding the effect of the regional party in the level of municipal transparency.

\section{Conclusions}

This paper aimed to analyse the drivers for information disclosure in the largest Spanish municipalities using panel data analysis. Since the large municipalities are relevant, the sample was partitioned into two categories according to the criteria: province capital municipalities 
and not province capital municipalities. The findings of this paper are a contribution to the flourishing body of evidence on this important vein of knowledge.

In the period under analysis, results suggested an increase in the level of information disclosure in Spanish municipalities, helping to legitimize their actions to citizens and reduce the problem of the agency. The greatest variation took place in 2012, which corresponds to a change in the electoral cycle due to the 2011 elections. Perhaps this was the consequence of social movements, such as "los indignados", whose origin was motivated by the plight of citizens. These findings are consistent with the existence of pressures from citizens regarding decision-making process and how resources are used, leading municipalities to reduce the asymmetry of information by disclosing information. It shows that municipal management changed towards more transparency, trying to respond to citizens and other stakeholders' pressures.

Furthermore, there is empirical evidence that certain internal and external factors of the municipalities influence information disclosure. The factors that have a significant effect on information disclosure and drive a more transparent communication process are: financial dependence, internet access, unemployment, electoral turnout, and political rivalry. Despite the initial expectations, political ideology had no significant effect on the level of information disclosure. Considering the province capital municipalities and those who are not province capital, the results show there are differences in the factors that influence information disclosure. Hence, for province capital municipalities, data suggested that external factors (unemployment, electoral turnout and internet access) have a significant effect on information disclosure. For the not province capital municipalities, both internal and external factors (financial dependence, political rivalry, unemployment and internet access) have a significant effect. On the other hand, variables such size of population, education level and region effect influenced information disclosure in the full sample. Despite the initial expectations, the regional party had no significant effect in the level of information disclosure in the full sample; these results were similar for those municipalities that are not province capital. However, these variables had no significant influence in the province capital municipalities.

Nevertheless, the difference found on municipalities suggests that institutional characteristics could influence information disclosure. Internal features of the municipalities, such as organizational complexity and culture and the style of public management, among others, could influence the level of information disclosure. This is worth to study in further studies.

The findings are in line with the Agency Theory, which postulate the existence of pressure from citizens on how decisions and actions are taken, leading municipalities to reduce asymmetry of information by disclosing information. In the same way, according to the Theory of Legitimacy, municipalities increased the levels of information disclosure as a way to legitimize the actions of political leaders toward citizens. This suggests that citizens are demanding more 
openness and information from politicians due to the loss of confidence in them.

One of the main implications for practitioners is that information disclosure is a key aspect to reduce information asymmetry between citizens and politicians, improve the communication process and increase accountability. The higher the social engagement and transparency, the more legitimate is the decision-making process of municipalities. Governments should enhance the mechanisms for information disclosure, working side by side with international organizations to learn from the international experience. On the other hand, international organizations should encourage central governments to foster information disclosure, accountability and transparency.

As for the limitations of this research, one has to point out data availability. Information disclosure was measured with a proxy for the transparency index. The transparency index focuses on the supply side, and it does not consider whether the information available to citizens is complete, reliable, timely, easily comprehensible and accessible. However, the study does not analyse how citizens perceive the information. It would be interesting to have extensive questionnaires from citizens in each of the 100 municipalities included in the dataset, in order to assess their level of knowledge on their municipality's activities and decisions. These topics would help expand the understanding on municipalities' disclosure management. Since information disclosure is a complex issue, future research should analyse the influence of other municipal internal factors, like cultural aspects, strategic management, decision-making process, which could influence information disclosure and transparency.

\section{Acknowledgment}

This study was conducted at the Research Center in Political Science (UIDB/ CPO/00758/2020), University of Minho/University of Évora and supported by the Portuguese Foundation for Science and Technology (FCT) and the Portuguese Ministry of Education and Science through national funds

\section{References}

Albalate, D. (2013), The institutional, economic and social determinants of local government transparency. Journal of Economic Policy Reform, 16(1), 90-107. https://doi.org/1 0.1080/17487870.2012.759422

Alcaide-Muñoz, L., Rodríguez-Bolívar, M. P., and López-Hernández, A. M. (2013), Financial determinants for improving public sector accountability: a meta-analytic study. Tran- 
sylvanian Review of dministrative Sciences, 9, 66-87

Alcaide Munoz, L., Rodriguez Bolivar, M. P. and Lopez Hernandez, A. M. (2017), Transparency in governments: a meta-analytic review of incentives for digital versus hard-copy public financial disclosures. The American Review of Public Administration, 47(5), 550573. https://doi.org/10.1177/0275074016629008

Alcaraz-Quiles, F. J., Navarro-Galera, A., and Ortiz-Rodríguez, D. (2015), Factors determining online sustainability reporting by local governments. International Review of Administrative Sciences, 81(1), 79-109. https://doi.org/10.1177/0020852314541564

Arapis, T., \& Reitano, V. (2018), Examining the evolution of cross-national fiscal transparency. The American Review of Public Administration, 48(6), 550-564. https://doi. org/10.1177/0275074017706740

Araujo, J. F. F. E. D., and Tejedo-Romero, F. (2016), Local government transparency index: determinants of municipalities' rankings. International Journal of Public Sector Management, 29(4), 327-347. https://doi.org/10.1108/ijpsm-11-2015-0199

Arellano, M. \& Bond, S. (1991), Some tests of specification for panel data: Monte Carlo evidence and an application to employment equations. The Review of Economic Studies, 58(2), 277-297. https://doi.org/10.2307/2297968

Armstrong, C. L. (2011), Providing a clearer view: An examination of transparency on local government websites. Government Information Quarterly, 28(1), 11-16. https://doi. org/10.1016/j.giq.2010.07.006

Baber, W.R., (1983), Towards understanding the role of auditing in the public sector. Journal of Accounting and Economics, 5(3), 213-227. https://doi.org/10.1016/01654101(83)90013-7

Baber, W. R., and Sen, P. K. (1984), The role of generally accepted reporting methods in the public sector: An empirical test. Journal of Accounting and Public Policy, 3(2), 91-106. https://doi.org/10.1016/0278-4254(84)90002-4

Ball, C. (2009), What is transparency? Public Integrity, 11(4), 293-308. https://doi. org/10.2753/pin1099-9922110400

Baltagi, B. (2014). Econometric analysis of panel data. London, England: Wiley

Bauhr, M., and Grimes, M. (2013), Indignation or Resignation: The Implications of Transparency for Societal Accountability. Governance, 27(2), 291-320. https://doi.org/10.1111/ gove. 12033

Blundell, R. \& Bond, S. (1998), Initial conditions and moment restrictions in dynamic panel data models, Journal of Econometrics, 87(1), 115-143. https://doi.org/10.1016/S03044076(98)00009-8

Caamaño-Alegre, J., Lago-Peñas, S., Reyes-Santias, F., and Santiago-Boubeta, A. (2013). Budget transparency in local governments: an empirical analysis. Local Government Studies, 39(2), 182-207. https://doi.org/10.1080/03003930.2012.693075

Caba-Pérez, C., Rodríguez Bolívar, M. P., and López Hernández, A. M. (2008), E- Government process and incentives for online public financial information. Online Information 
Review, 32(3), 379-400. https://doi.org/10.1108/14684520810889682

Caba-Pérez, M. d. C., Rodríguez-Bolivar, M. P., and López-Hernández, A. M. (2014), The determinants of government financial reports online. Transylvanian Review of Administrative Sciences, 42, 5-32

Cuadrado-Ballesteros, B. (2014), The impact of functional decentralization and externalization on local government transparency. Government Information Quarterly, 31(2), 265277. https://doi.org/10.1016/j.giq.2013.10.012

Cárcaba-García, A., and García-García, J. (2010), Determinants of online reporting of accounting information by Spanish local government authorities. Local Government Studies, 36(5), 679-695. https://doi.org/10.1080/03003930.2010.506980

Cucciniello, M., Porumbescu, G. A., \& Grimmelikhuijsen, S. (2017), 25 Years of Transparency Research: Evidence and Future Directions. Public Administration Review, 77(1), 32-44. https://doi.org/10.1111/puar.12685

Chortareas, G., Logothetis, V., and Papandreou, A. A. (2016), Political budget cycles and reelection prospects in Greece's municipalities. European Journal of Political Economy, 43, 1-13. https://doi.org/10.1016/j.ejpoleco.2016.02.001

Eisenhardt, K. M. (1989), Agency Theory: An Assessment and Review. Academy of Management Review, 14(1), 57-74. https://doi.org/10.2307/258191

Ellis, C. J. \& Fender, J. (2006), Corruption and transparency in a growth model. International Tax and Public Finance, 13(2-3), 115-149. https://doi.org/10.2139/ssrn.436505

Fung, A. (2013), Infotopia unleashing the democratic power of transparency. Politics \& Society, 41(2), 183-212. https://doi.org/10.1177/0032329213483107

García-Sánchez, I. M., Frías-Aceituno, J. V., \& Rodríguez-Domínguez, L. (2013), Determinants of corporate social disclosure in Spanish local governments. Journal of Cleaner Production, 39, 60-72. https://doi.org/10.1016/j.jclepro.2012.08.037

Gonzalez, R., Gasco, J., \& Llopis, J. (2007). E-government success: some principles from a Spanish case study. Industrial Management \& Data Systems, 107(6), 845-861. https:// doi.org/10.1108/02635570710758752

Greco, G., Sciulli, N., \& D’onza, G. (2012), From Tuscany to Victoria: some determinants of sustainability reporting by local councils. Local Government Studies, 38(5), 681-705. https://doi.org/10.1080/03003930.2012.679932

Guillamón, M. D., Bastida, F., \& Benito, B. (2011). The determinants of local government's financial transparency. Local Government Studies, 37(4), 391-406. https://doi.org/10.10 80/03003930.2011.588704

Ingram, R. W., \& DeJong, D. V. (1987), The effect of regulation on local government disclosure practices. Journal of Accounting and Public Policy, 6(4), 245-270. https://doi. org/10.1016/s0278-4254(87)80002-9

Krippendorff, K. (2004), Content analysis: An introduction to its methodology. California: Sage Publications, Inc. ISBN 0-7619-1545-1

Lane, J. E. (2005). Public administration and public management: The principal agent per- 
spective. London, England: Taylor \& Francis

Laswad, F., Fisher, R., \& Oyelere, P. (2005), Determinants of voluntary Internet financial reporting by local government authorities. Journal of Accounting and Public Policy, 24(2), 101-121. https://doi.org/10.1016/j.jaccpubpol.2004.12.006

Lopes, I. T., \& Serrasqueiro, R. M. (2017), The influence of culture and transparency on global research and development intensity: An overview across Europe. Contaduría y administración, 62(4), 1408-1422. http://dx.doi.org/10.1016/j.cya.2017.06.002

Lowatcharin, G., \& Menifield, C. E. (2015). Determinants of Internet-enabled transparency at the local level: A study of Midwestern county web sites. State and Local Government Review, 47(2), 102-115. https://doi.org/10.1177/0160323X15593384

OECD. (2014), Factbook 2014: Economic, Environmental and Social Statistics: OECD Publishing. https://doi.org/10.1787/18147364

Ortiz-Rodríguez, D., Navarro-Galera, A., \& Alcaraz-Quiles, F. J. (2015), The Influence of Administrative Culture on Sustainability Transparency in European Local Governments. Administration \& Society, 50(4), 555-594. https://doi.org/10.1177/0095399715616838

Osborne, S. P. (2006), The new public governance? Public Management Review, 8, 377-387. https://doi.org/10.1080/14719030600853022

Park, H., \& Blenkinsopp, J. (2011), The roles of transparency and trust in the relationship between corruption and citizen satisfaction. International Review of Administrative Sciences, 77(2), 254-274. https://doi.org/10.1177/0020852311399230

Patten, D. M. (1992), Intra-industry environmental disclosures in response to the Alaskan oil spill: A note on legitimacy theory. Accounting, Organizations and Society, 17, 471-475. https://doi.org/10.1016/0361-3682(92)90042-q

Pina, V., Torres, L. \& Royo, S. (2010), Is E-government Promoting Convergence Towards More Accountable Local Governments? International Public Management Journal, 13(4), 350-380. https://doi.org/10.1080/10967494.2010.524834

Piotrowski, S. J., \& Van Ryzin, G. G. (2007), Citizen attitudes towards transparency in local government. American Review of Public Administration, 37(3), 306-323. https://doi. org/10.1177/0275074006296777

Roberts, A. (2006), Dashed expectations: Governmental adaptation to transparency rules. En Christopher Hood and David Heald (Coord.), Transparency: The Key to Better Governance?. (pp. 107-125). Oxford: British Academy Scholarship Online. https://doi. org/10.5871/bacad/9780197263839.003.0007

Rodríguez-Bolívar, M. P., Alcaide-Muñoz, L., \& López-Hernández, A. M. (2013), Determinants of financial transparency in government. International Public Management Journal, 16(4), 557-602. https://doi.org/10.1080/10967494.2013.849169

Rodríguez, L., García, I. M., \& Gallego, I. (2011). From emerging to connected e- Government: The effects of socioeconomics and internal administration characteristics. The International Journal of Digital Accounting Research, 11(1), 85-109

Roodman, D. (2006), How to do xtabond2: An introduction to difference and system gmm 
in stata. Stata Journal, 9(1), 86-136. https://doi.org/10.2139/ssrn.982943

Ruijer, H. J. M. (2016), Proactive Transparency in the United States and the Netherlands: The Role of Government Communication Officials. The American Review of Public Administration, 47(3), 354-375. https://doi.org/10.1177/0275074016628176

Suchman, M. C. (1995), Managing legitimacy: strategic and institutional approaches. Academy of Management Review, 20(3), 571-610. https://doi.org/10.2307/258788

Tejedo-Romero, F., \& Araujo, J. F. F. E. (2018). Determinants of local governments' transparency in times of crisis: evidence from municipality-level panel data. Administration \& Society, 50(4), 527-554. https://doi.org/10.1177/0095399715607288

Windmeijer, F. (2005), A finite sample correction for the variance of linear efficient twostep GMM estimators. Journal of econometrics, 126(1), 25-51. https://doi.org/10.1016/j. jeconom.2004.02.005

Zimmerman, J.L.(1977), The municipal accounting maze: An analysis of political incentives. Journal of Accounting Research, 15(Suppl.), 107-144. https://doi.org/10.2307/2490636 